Jurnal Ilmiah SEMANTIKA

Volume 2, No. 02, Februari 2021, p. 1-9

\title{
Pengembangan Bahan Ajar BIPA Tingkat 3 Berbasis Budaya Lokal Malang
}

\author{
Development of Level 3 BIPA Teaching Materials Based on Malang Local Culture
}

\author{
Helmi Muzaki \\ Program Studi Sastra, Fakultas Sastra, Universitas Negeri Malang, Indonesia \\ e-mail:helmi.muzaki@um.ac.id
}

\begin{abstract}
ABSTRAK
Pengajaran Bahasa Indonesia bagi Penutur Asing (BIPA) mempunyai misi yang sangat penting yaitu memperkenalkan bahasa dan budaya Indonesia kepada masyarakat internasional serta meningkatkan mutu pengajaran BIPA. Untuk mewujudkan misi tersebut diperlukan berbagai upaya, salah satunya ketersedian bahan ajar yang sesuai dengan kebutuhan dan bermuatan budaya. Namun, berdasarkan observasi yang dilakukan penulis, penulis menemukan beberapa fakta yaitu masih kurangnya bahan ajar yang sesuai dengan kebutuhan dan kurangnya bahan ajar yang membahas budaya lokal Malang khususnya untuk bahan ajar BIPA tingkat 3. Tujuan dari penelitian adalah untuk mengembangkan bahan ajar BIPA tingkat 3 berbasis budaya lokal Malang dengan acuan SKL BIPA. Penelitian dan pengembangan ini menggunakan model pengembangan Borg \& Gall dengan modifikasi tahapan sesuai kebutuhan penelitian dan pengembangan bahan ajar. Penulis melakukan penyesuaian dengan membatasi penelitian sampai pada tujuh tahap. Bahan ajar yang dikembangkan terintegrasi dengan empat keterampilan berbahasa yaitu: menyimak, berbicara, membaca, dan menulis. Dalam setiap unit bahan ajar, terdapat materi budaya lokal Malang baik secara eksplisit maupun implisit

Kata kunci: Bahan Ajar, BIPA, Budaya
\end{abstract}

\begin{abstract}
Indonesian for Foreign Speakers (BIPA) has a very important mission, that is introducing Indonesian and language culture to the international community and improving the quality of BIPA teaching. To realize this mission, various efforts are needed, one of them is the teaching material according to BIPA student needs and have cultural content. However, based on observations, the writer found several facts namely, the lack of teaching materials according to student needs and the Lack of teaching materials that discuss Malang local culture, especially for BIPA level 3 teaching materials. The purpose of this research is to develop BIPA level 3 teaching materials development based on Malang local culture with reference to SKL BIPA. This research and development uses the development model of Borg \& Gall with modification of the stages according to research and learning materials development needs. The author made adjustments by limiting the research to seven stages. The teaching materials developed are integrated with four language skills, that is: listening, speaking, reading, and writing. In each unit of teaching materials, there are Malang local cultural materials, both explicitly and implicitly
\end{abstract}

Keywords: Teaching Materials, BIPA, Malang Culture

\section{PENDAHULUAN}

BIPA adalah kepanjangan dari Bahasa Indonesia bagi Penutur Asing. BIPA (bahasa Indonesia untuk penutur asing) dapat diartikan sebagai program pembelajaran bahasa yang secara khusus dirancang untuk pembelajar atau siswa asing yang ingin belajar bahasa Indonesia[1]. BIPA adalah sebuah program pembelajaran bahasa Indonesia yang subjeknya merupakan pembelajar asing[2]. Hal senada juga disampaikan Yahya yang menyatakan bahwa BIPA merupakan pembelajaran bahasa Indonesia yang subjeknya adalah pembelajar asing[3]. Jadi BIPA dapat diartikan sebagai sebuah program pembelajaran bahasa Indonesia yang diperuntukan khusus untuk warga negara asing yang bahasa pertamanya bukan bahasa Indonesia atau bahasa daerah. 
Pengajaran Bahasa Indonesia bagi Penutur Asing (BIPA) merupakan salah satu upaya dalam rangka mendukung pemerintah untuk meningkatkan fungsi Bahasa Indonesia menjadi bahasa internasional. Peningkatan fungsi bahasa Indonesia tersebut tentu akan berdampak pada peningkatan posisi Indonesia di kancah dunia internasional, yaitu memperkuat jati diri bangsa dan meningkatkan daya saing bangsa. Wujud pencapaian Bahasa Indonesia sebagai bahasa internasional sehingga bahasa Indonesia dapat digunakan sebagai bahasa resmi pada pertemuanpertemuan antar negara dan digunakan sebagai bahasa penghubung dalam berbagai kepentingan politik, sosial, budaya, dan ekonomi antarnegara.

Pengajaran BIPA mempunyai peran yang sangat penting dalam memperkenalkan Indonesia kepada masyarakat internasional serta sebagai satu alat diplomasi bangsa Indonesia. Bahasa Indonesia bagi Penutur Asing (BIPA) merupakan salah satu alat diplomasi yang dapat digunakan oleh pemerintah Indonesia dalam upaya memperkuat posisi Indonesia dalam percaturan dunia[4]. Melalui BIPA, negara lain dapat mengenal bahasa Indonesia dan budaya Indonesia

Salah satu tujuan BIPA adalah memperkenalkan bahasa dan budaya Indonesia ke dunia internasional dalam rangka meningkatkan citra positif Indonesia di luar negeri dan meningkatkan mutu pengajaran BIPA[5]. Untuk mewujudkan misi tersebut diperlukan berbagai upaya, salah satunya ketersedian bahan. Bahan ajar yang sesuai adalah salah satu faktor penting untuk mencapai kesuksesan dalam pembelajaran bahasa[6]. Oleh karena itu, dalam pembuatan bahan ajar penulis perlu memperhatikan kebutuhan pembelajaran BIPA.

Di dalam pengembangan bahan ajar BIPA salah satu yang perlu diperhatikan adalah aspek budaya. Unsur budaya memiliki peranan yang sangat penting dalam memenuhi target pembelajaran BIPA[7]. Oleh karena itu, dalam pengembangan bahan ajar BIPA perlu menambahkan unsur budaya. Pemahaman budaya khususnya budaya lokal sangat diperlukan bagi pembelajar BIPA untuk mengurangi gegar budaya. Pemahaman budaya akan membuat mahasiswa asing terhindar dari gegar budaya yang berlebihan[8]. Bahasa dan budaya merupakan satu kesatuan yang tidak dapat dipisahkan satu sama lain. Belajar bahasa tidak dapat dipisahkan dari budaya[9]. Oleh karena itu, seseorang dikatakan mahir berbahasa apabila dia sudah menguasai bahasa dan budayanya. Artinya dalam belajar bahasa Indonesia pebelajar BIPA juga harus belajar budayanya khususnya budaya dimana pebelajar BIPA tinggal karena setiap hari mereka berinteraksi dengan masyarakat disekitar tempat tinggal mereka. Oleh karena itu, pengelola dan pengajar BIPA harus menyusun bahan ajar atau mengembangkan bahan ajar yang bermuatan budaya dan sesuai dengan kebutuhan pebelajar BIPA.

Dalam pengembangan bahan ajar BIPA salah satu yang perlu diperhatikan adalah keterampilan berbahasa pebelajar BIPA berbeda-beda. Oleh karena itu, perlu ditentukkan pengembangan bahan ajar untuk tingkat apa. Secara umum ada 4 pedoman pemeringkatan bahan ajar BIPA yang sering digunakan di Indonesia yaitu berdasarkan CEFR, ACTFL, UKBI, dan Permendikbud Nomor 27 Tahun 2017 tentang Standar Kompetensi Lulusan (SKL) BIPA. Berikut rincian pemeringkatan tersebut.

Pertama, pemeringkatan BIPA berdasarkan CEFR (Common European Framework of Reference) merupakan kerangka acuan bahasa asing di wilayah Eropa. Bahasa Indonesia dalam konteks ini setara dengan bahasa Indonesia sebagai bahasa asing. CEFR membagi kerangka acuan menjadi 6 tingkat, yaitu A1, A2, B1, B2, C1 dan C2. Makna dari pembagian tingkatan tersebut adalah: (1) A1 artinya tingkat pemula bawah, (2)A2 artinya tingkat pemula atas, (3) B1 artinya tingkat madya bawah (4) B2 artinya tingkat madya atas, (5) C1 artinya tingkat unggul dan (6) C2 artinya tingkat sangat unggul. Pemeringkatan model CEFR ini digunakan oleh PPSDK dan beberapa Lembaga penyelenggara BIPA salah satunya untuk program Darmasiswa.

Kedua, pemeringkatan BIPA oleh ACTFL (American Council for Teaching Foreign Language). ACTFL merupakan kerangka acuan yang menyajikan tingkat kemampuan seseorang dalam berbahasa pada setiap tingkatan, Menurut ACTFL pemeringkatan BIPA dibagi menjadi 11 tingkatan yaitu: (1) distinguished atau istimewa, (2) superior atau unggul, (3) advance high atau mahir tinggi, (4) advance mid atau mahir menengah, (5) advance low atau mahir rendah, (6) intermediate high atau madya tinggi, (7) intermediate mid atau madya menengah, (8) intermediate 
low atau madya rendah, (9) novice high atau pemula tinggi, (10) novice mid atau pemula menengah, dan (11) novice low atau pemula rendah.

Ketiga, pemeringkatan oleh Badan Pengembangan dan Pembinaan Bahasa melui UKBI. Dalam pemeringkatan ini kemampuan Bahasa Indonesia diklasifikasikan menjadi 7 peringkat, yaitu: (1) Terbatas, (2) Marginal, (3) Semenjana, (4) Madya, (5) Unggul, (6) Sangat Unggul dan (7) Istimewa.

Keempat, pemeringkatan BIPA menurut Permendikbud Nomor 27 Tahun 2017 yang di dalamnya terdapat Standar Kompetensi Lulusan (SKL) BIPA. SKL BIPA merupakan salah satu pedoman dalam merumuskan kurikulum, menentukan bahan ajar, merencanakan dan melaksanakan pembelajaran, serta menentukan lulusan pembelajar BIPA pada lembaga kursus dan pelatihan, Menurut SKL pemeringkatan BIPA dibagi menjadi 7, diantaranya: (1) BIPA 1, (2) BIPA 2. (3) BIPA 3, (4) BIPA 4, (5) BIPA 5, (6) BIPA 6 dan (7) BIPA 7.

Berdasarkan observasi yang dilakukan penulis, penulis menemukan beberapa fakta yaitu masih kurangnya bahan ajar yang sesuai dengan minat dan perkembangan mahasiswa dan kurangnya bahan ajar yang membahas budaya lokal Malang khususnya untuk bahan ajar BIPA tingkat 3. Hasil temuan penulis sesuai dengan pendapat Pangesti dan Wuriatno yang menyatakan bahwa ketersediaan bahan ajar BIPA menjadi isu yang terus berkembang dari tahun ke tahun karena bahan ajar yang ada belum memenuhi kebutuhan pengajar dan pembelajar BIPA[10]. Jika kurangnya bahan ajar BIPA tidak segera diatasi maka bisa berdampak buruk pada kualitas pembelajaran BIPA. Kurangnya bahan ajar akan mempengaruhi kualitas pembelajaran[11]. Salah satu solusi dari masalah tersebut adalah penyusunan bahan ajar BIPA berbasis budaya lokal Malang untuk mahasiswa BIPA tingkat 3. Pada penelitian ini penulis menggunakan pemeringkatan sesuai dengan Permendikbud Nomor 27 Tahun 2017 tentang Standar Kompetensi Lulusan (SKL) BIPA karena SKL BIPA dapat dijadikan pedoman dalam pengembangan bahan ajar BIPA dan bahan ajar ini dibuat salah satunya untuk pebelajar BIPA Darmasiswa di bawah naungan Kemendikbud.

Bahan ajar yang disusun diharapkan dapat digunakan sebagai bahan ajar dalam pembelajaran BIPA untuk pebelajar BIPA tingkat 3, dapat meningkatkan keterampilan penutur asing tingkat BIPA 3 dalam berbahasa Indonesia dan dapat meningkatkan pengetahuan penutur asing terhadap budaya Indonesia khususnya budaya Malang

\section{METODOLOGI PENELITIAN}

Penelitian dan pengembangan ini menggunakan model modifikasi tahapan sesuai kebutuhan penelitian dan pengembangan, dimana penulis melakukan penyesuaian dengan membatasi penelitian sampai pada tujuh tahap. Tujuh tahapan yang dimaksud dalam penelitian ini yaitu adalah (1) analisis kebutuhan dan pengumpulan informasi awal, (2) perencanaan penelitian, (3) pengembangan format produk awal, (4) validasi produk, (5) revisi produk pertama, (6) uji coba produk, dan (7) revisi produk[12]. Prosedur penelitian yang dilakukan dalam penelitian pengembangan ini terdapat pada Gambar 1. 
Jurnal SEMANTIKA, Volume 2, No. 02, Februari 2021, pp. 1-9

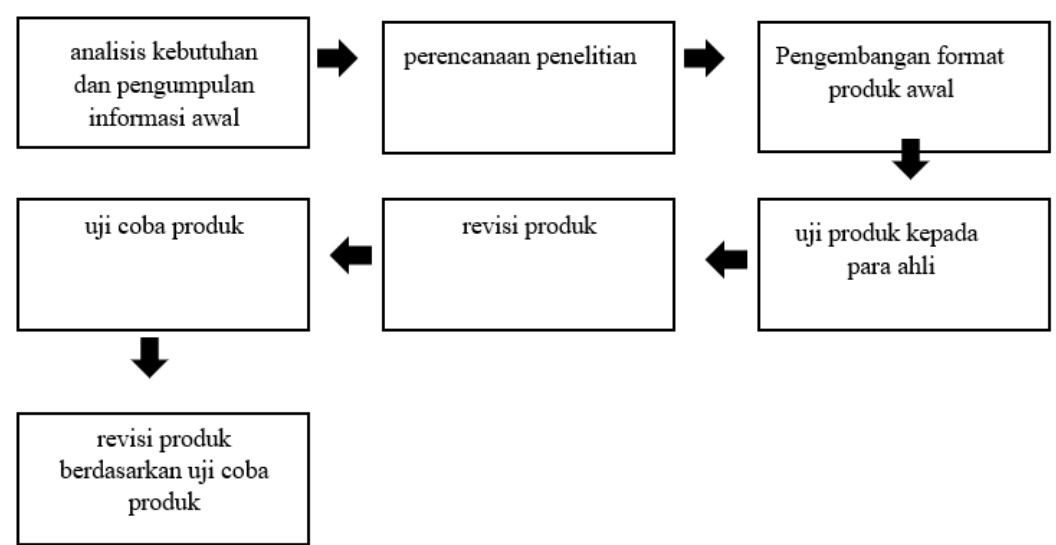

Gambar 1. Bagan pengembangan bahan ajar BIPA tingkat 3

Tahap Pertama analisis kebutuhan dan pengumpulan informasi awal, analisis kebutuhan perlu dilakukan untuk menyesuaikan materi dengan kebutuhan pebelajar BIPA sehingga nantinya pembelajaran BIPA bisa lebih efektif dan efisien. Materi ajar yang dibutuhkan oleh pebelajar BIPA sangat tergantung pada kebutuhan[13]. Pada tahap analisis kebutuhan dan pengumpulan informasi awal penulis melakukan wawancara dengan dosen sekaligus pengelola BIPA dan wawancara kepada pebelajar BIPA. Wawancara dilakukan untuk memperoleh data analisis kebutuhan awal pebelajar BIPA.

Tahap Kedua, perencanaan penelitian. Pada tahap ini penulis menyusun draft bahan ajar yang meliputi merumuskan tujuan, menentukan bahan ajar yang sesuai dengan kebutuhan dan standar kompetensi lulusan BIPA tingkat 3 serta menentukan alat penilaian atau evaluasi.

Tahap ketiga, pengembangan produk dilakukan dengan cara membuat bahan ajar BIPA. Bahan ajar disusun dan disesuaikan dengan analisis kebutuhan dan standar kompetensi lulusan BIPA 3. Pembuatan bahan ajar membaca dimulai dengan mencari dan menyesuaikan tema-tema yang akan digunakan dalam bahan ajar. Langkah selanjutnya membuat latihan soal sesuai dengan teks dan menyiapkan perangkat penilaian bahan ajar. Tahap keempat bahan ajar yang sudah dibuat, divalidasi ahli BIPA dan ahli Bahasa Indonesia untuk dinilai kelayakannnya supaya bahan ajar lebih baik sebelum uji coba.

Tahap kelima revisi produk berdasarkan saran dan masukan dari ahli BIPA dan ahli Bahasa Indonesia. Hasil kegiatan tahap ini berupa bahan ajar BIPA tingkat 3 yang sudah diperbaiki sesuai dengan saran dari ahli BIPA dan ahli Bahasa Indonesia. Tahap keenam, uji coba produk dilakukan pada mahasiswa BIPA Darmasiswa. Dalam uji coba ini, disiapkan pula angket untuk mahasiswa. Angket tersebut bertujuan untuk mengetahui keefektifan dan kesesuaian bahan ajar yang diujicobakan. Tahap ketujuh, revisi produk dilakukan setelah melakukan uji coba. Revisi produk dilakukan berdasarkan hasil analisis angket dari mahasiswa. Kritik dan saran yang diberikan di dalam angket dijadikan pedoman revisi produk bahan ajar.

\section{HASIL DAN PEMBAHASAN}

\section{Deskripsi Produk}

Bahan ajar yang dihasilkan adalah bahan ajar dengan bentuk bahan ajar cetak dan PDF yang ditujukan untuk pebelajar BIPA tingkat 3 yang mengikuti program Darmasiswa. Bahan ajar ini dapat digunakan sebagai bahan ajar utama atau bahan ajar pendamping untuk belajar di kelas, baik kelas klasikal maupun kelas online dengan bimbingan pengajar. 
Bahan ajar yang dikembangkan terdiri atas 3 unit dan setiap unit dilengkapi dengan tujuan pembelajaran serta kosa-kata penting. 3 unit tersebut yaitu Teks Deskripsi, Teks Narasi, dan Teks Eksplanasi. Setiap unit terdiri atas 4 bagian pembelajaran yang terintegrasi ke dalam 4 keterampilan yaitu: menyimak, berbicara, membaca, dan menulis. Dalam setiap unit bahan ajar terdapat materi budaya lokal Malang baik secara eksplisit maupun implisit. Rincian bahan ajar yang dikembangkan adalah sebagai berikut:

Unit 1 memaparkan materi teks deskripsi dengan 4 keterampilan berbahasa yaitu: keterampilan menyimak, keterampilan membaca, keterampilan berbicara dan keterampilan menulis. Adapun rincian materinya adalah sebagai berikut. Materi keterampilan menyimak meliputi menyimak dialog berkaitan dengan liburan di Pantai Teluk Asmara dan Biro Perjalanan Wisata. Materi keterampilan membaca meliputi makanan khas Malang seperti Orem-orem dan Bakso Malang, tempat bersejarah, tempat penting dan tempat wisata di Malang seperti Candi Badut, RSUD Dr. Saiful Anwar, dan tempat wisata Pantai Balekambang. Materi keterampilan berbicara berkaitan dengan Museum Topeng Malang. Pebelajar BIPA mensimulasikan percakapan di Museum Topeng Malang dan kemudian pebelajar BIPA diminta menceritakan tempat wisata yang paling pebelajar sukai. Materi keterampilan menulis, pebelajar BIPA diminta menulis sebuah teks deskripsi dengan menggunakan struktur organisasi teks deskripsi dan ciri kebahasaan dengan tepat.

Unit 2 memaparkan materi teks narasi dengan 4 keterampilan berbahasa yaitu: keterampilan menyimak, keterampilan membaca, keterampilan berbicara dan keterampilan menulis. Adapun rincian materinya adalah sebagai berikut. Materi keterampilan menyimak yaitu menyimak Legenda Coban Rondo. Materi keterampilan membaca meliputi cerita dan legenda yang ada di Malang seperti Monumen Tugu, Asal Mula Nama Malang, Legenda Gunung Arjuna, dan Ken Arok. Materi keterampilan berbicara menceritakan sebuah legenda tempat wisata yang diketahui oleh pebelajar BIPA atau terkenal, dengan menggunakan struktur teks dan ciri kebahasaan teks narasi yang sudah dipelajari. Materi keterampilan menulis pebelajar BIPA diminta menulis sebuah legenda tempat wisata yang Anda tahu atau terkenal dengan menggunakan struktur organisasi teks narasi dan ciri kebahasaan dengan tepat.

Unit memaparkan materi teks eksplanasi dengan 4 keterampilan berbahasa yaitu: keterampilan menyimak, keterampilan membaca, keterampilan berbicara dan keterampilan menulis. Adapun rincian materinya adalah sebagai berikut. Materi keterampilan menyimak yaitu menyimak simakan dengan topik Demam Berdarah. Materi keterampilan membaca meliputi Virus Corona yang sedang mewabah dan Bahasa Walikan. Materi keterampilan berbicara yaitu menyimulasikan percakapan tentang Kesenian Bantengan. Materi keterampilan menulis pebelajar BIPA diminta menulis sebuah tentang fenomena alam maupun sosial yang terjadi di kehidupan sehari-hari.

\section{Analisis Kebutuhan Pebelajar BIPA}

Analisis kebutuhan pebelajar BIPA perlu dilakukan sebelum mengembangkan bahan ajar BIPA. Manfaat analisis kebutuhan pebelajar BIPA adalah supaya pengembang bahan ajar dapat mengetahui apa saja kebutuhan pebelajar BIPA. Adapun tujuan dari analisis kebutuhan untuk mengetahui alasan dan tujuan pebelajar BIPA dalam mempelajari bahasa Indonesia[14]. Bahan ajar yang dikembangkan berdasarkan analisis kebutuhan akan lebih memberi manfaat karena bahan ajar tersebut sesuai dengan kebutuhan pembejar BIPA. Berdasarkan hasil analisis kebutuhan, pebelajar BIPA tertarik pada tema:

a) Kuliner, temuan penulis bahwa pembelajar bipa tertarik pada tema kuliner sejalan dengan pendapat Hartono yang menyatakan bahwa materi kuliner perlu diperkenalkan dalam dunia internasional salah satunya dengan cara diintegrasikan ke dalam materi ajar BIPA[15].

b) Pariwisata, temuan penulis bahwa pembelajar BIPA tertarik pada tema pariwisata sejalan dengan hasil penelitian Kusmiatun yang menyatakan bahwa secara umum mahasiswa BIPA asal Tiongkok menyukai topik belajar pariwisata[16]. Serta pendapat Junaidi Pembelajaran BIPA berbasis budaya dapat dilakukan dengan berbagai cara, salah satunya memperkenalkan 
Jurnal SEMANTIKA, Volume 2, No. 02, Februari 2021, pp. 1-9

budaya fisik misalnya dengan memasukkan konten tempat-tempat wisata dan benda-benda yang menjadi ciri khas daerah tertentu[17].

c) Kesenian, pembelajar BIPA pada umumnya tertarik dengan tema kesenian Indonesia khususnya yang ada disekitar mereka. Nilai budaya lokal yang digunakan dalam bahan ajar BIPA dapat bersumber dari berbagai ranah kehidupan salah satunya kesenian[18].

d) Transportasi, Transportasi merupakan salah satu tema yang dipilih oleh pembelajar BIPA, transportasi merupakan bagian yang tidak bisa dipisahkan dalam kehidupan sehari-hari pembelajar BIPA yang ada di Indonesia. Berdasarkan temuan Sariningsih dkk, terjadi gegar budaya pembelajar BIPA pada saat menaiki transportasi di indonesia khususnya transportasi lokal[19]. Oleh karena itu, salah satu cara untuk mengurangi gegar budaya adalah dengan memberi pemahaman kepada pembelajar BIPA melalui materi transportasi yang ada dalam bahan ajar.

Setelah penulis memperoleh hasil analisis kebutuhan, tahap berikutnya penulis menyesuaikan kebutuhan pebelajar BIPA dengan SKL dengan rincian sebagai berikut:

1) Kebutuhan pengetahuan pebelajar BIPA tentang kuliner berkaitan dengan SKL memahami teks deskripsi yaitu materi Orem-orem dan Bakso Malang.

2) Kebutuhan pengetahuan pebelajar BIPA tentang pariwisata berkaitan dengan SKL memahami teks deskripsi yaitu materi Pantai Teluk Asmara, Biro Perjalanan Wisata, Candi Badut, Pantai Balekambang. Selain itu kebutuhan pebelajar BIPA Darmasiswa tentang pariwisata berkaitan dengan SKL memahami teks narasi yaitu materi tentang Legenda Coban Rondo, Monumen Tugu dan Legenda Gunung Arjuna.

3) Kebutuhan pengetahuan pebelajar BIPA tentang kesenian berkaitan dengan SKL memahami teks deskripsi yaitu materi Museum Topeng Malang dan juga berkaitan dengan SKL memahami teks eksplanasi yaitu materi tentang kesenian Bantengan.

4) Kebutuhan pengetahuan pebelajar BIPA tentang transportasi berkaitan dengan SKL memahami teks deskripsi yaitu materi Museum Angkut.

Selain itu penulis juga menambahkan materi yang menurut penulis perlu diajarkan dan sesuai dengan SKL BIPA diantaranya;

1) penambahan materi teks eksplanasi tentang Demam Berdarah (DBD) karena penyakit DBD merupakan penyakit musiman yang selalu melanda Indonesia termasuk di Malang. Oleh karena itu, mahasiswa BIPA perlu mengetahui cara mencegah, gejala dan penanganannya tujuannya untuk melindungi penduduk (mahasiswa BIPA) dari Penyakit DBD sedini mungkin, meningkatkan kemampuan masyarakat untuk hidup sehat.

2) Penambahan materi teks eksplanasi tentang Virus Corona karena Virus Corona adalah virus yang mudah menular dan sekarang sudah mewabah hampir di seluruh dunia termasuk di Kota Malang oleh karena itu mahasiswa BIPA perlu diberi informasi tentang Virus Corona untuk mencegah penyebaran Virus Corona.

3) Penambahan teks deskripsi RSUD Dr. Saiful Anwar penulis berpendapat pengetahuan lokasi rumah sakit sangat penting diketahui oleh pebelajar BIPA khususnya pada masa pandemi covid 19.

\section{Uji Produk}

Uji produk atau validasi produk dilakukan oleh ahli Bahasa Indonesia dan ahli BIPA. Secara garis besar catatan yang diberikan oleh validator adalah:

1. materi perlu ditambahkan dengan materi tempat bersejarah dan tempat-tempat penting;

2. pada bagian kosa kata baru seharusnya dibuat lebih sederhana;

3. pada unit satu tentang teks deskripsi sebaiknya diberi judul atau pengantar, jangan tibatiba langsung teori tentang teks deskripsi;

4. kosa-kata baru maksimal 10 kata, namun mudah untuk dipahami;

5. link untuk bahan menyimak disertakan langsung dalam instruksi materi menyimak;

6. teks-teks yang digunakan lebih baik pada tempat-tempat yang dekat dengan tempat belajar. 


\section{Revisi Produk Pertama}

Revisi produk dilakukan supaya bahan ajar yang dihasilkan lebih baik dan lebih mudah dipahami oleh pebelajar BIPA. Adapun kegiatan yang dilakukan penulis adalah melakukan perbaikan sesuai dengan saran dari para validator.

\section{Uji coba produk}

Uji coba produk dilakukan untuk mengetahui kelemahan atau keberhasilan dari produk bahan ajar yang dikembangkan. Bahan ajar diujicobakan kepada pebelajar BIPA Darmasiswa tingkat 3. Setelah proses uji coba penulis membagi angket evaluasi bahan ajar kepada pebelajar BIPA Darmasiswa menggunakan skala 1-5 dan melakukan wawancara kepada pebelajar BIPA untuk memperoleh saran atau masukan dari pebelajar BIPA. Adapun hasil angket evaluasi bahan Ajar BIPA tingkat 3 yaitu:

1) kesesuaian dengan kebutuhan pebelajar BIPA mendapat nilai 5 artinya bahan ajar BIPA sangat sesuai dengan kebutuhan pebelajar BIPA;

2) topik menarik untuk dipelajari mendapat nilai 4,6 artinya topik yang dibahas dalam bahan ajar BIPA menurut pebelajar BIPA sangat menarik;

3) topik yang dibahas bermanfaat mendapat nilai 4,6 artinya topik yang dibahas bermanfaat bermanfaat bagi pebelajar BIPA;

4) kesesuaian materi dengan budaya lokal Malang mendapat nilai 4,3 artinya materi yang ada dalam bahan bahan ajar BIPA sesuai dengan budaya lokal Malang;

5) keterbacaan bahan ajar BIPA mendapat nilai 4,6 artinya bahan ajar BIPA mudah dibaca dan dipahami;

6) kejelasan informasi bahan ajar BIPA mendapat nilai 4 artinya informasi yang ada dalam bahan ajar BIPA mudah dipahami atau dimengerti;

7) kejelasan tujuan bahan ajar BIPA mendapat nilai 4,3 artinya dilihat dari aspek kejelasan tujuan bahan ajar BIPA sudah baik dan dapat dipahami oleh pebelajar BIPA;

8) urutan penyajian bahan ajar BIPA mendapat nilai 4,3 artinya dilihat dari aspek urutan penyajian bahan ajar BIPA penyajian bahan ajar BIPA dalam kategori baik;

9) ilustrasi, gambar dan foto bahan ajar BIPA mendapat nilai 4,6 artinya dari segi Ilustrasi, gambar dan foto, bahan ajar BIPA dalam kategori baik, gambar atau foto jelas dan menggambarkan materi yang dibahas;

10) desain tampilan bahan ajar BIPA mendapat nilai 4,6 artinya dari segi desain tampilan, bahan ajar BIPA dalam kategori baik.

Hasil wawancara dengan pebelajar BIPA penulis mendapatkan saran supaya memasukan materi sejarah Malang.

\section{Revisi Produk Kedua}

Revisi produk dilakukan supaya bahan ajar yang dihasilkan lebih baik dan sesuai dengan harapan. Adapun kegiatan yang dilakukan penulis adalah melakukan perbaikan menambahkan materi tentang sejarah malang sesuai dengan saran pebelajar BIPA.

\section{SIMPULAN}

Bahan ajar yang dihasilkan adalah bahan ajar berbentuk Pdf sehingga mudah untuk didistribusikan khususnya pada saat pandemi Covid 19. Bahan ajar terdiri atas 3 unit dan setiap unit dilengkapi dengan tujuan pembelajaran serta kosa-kata penting. 3 unit tersebut yaitu: Teks Deskripsi, Teks Narasi, dan Teks Eksplanasi. Setiap unit memiliki 4 bagian pembelajaran yang terintegrasi ke dalam 4 keterampilan yaitu: menyimak, berbicara, membaca, dan menulis. Dalam setiap unit bahan ajar, terdapat materi budaya lokal Malang baik secara eksplisit maupun implisit. Bahan ajar yang dihasilkan dapat digunakan sebagai bahan ajar utama atau bahan ajar pendamping untuk pebelajar BIPA tingkat 3 dan dapat digunakan digunakan untuk pembelajaran 
yang dilakukan secara luring atau pembelajaran yang dilakukan secara daring dengan bimbingan pengajar.

Bahan ajar yang dibutuhkan oleh pebelajar BIPA sangat tergantung pada kebutuhan belajar pebelajar BIPA. Oleh karena itu, disarankan kepada pengelola dan pengajar BIPA, dalam memilih bahan ajar BIPA sebaiknya memilih bahan ajar yang lebih beragam sehingga dapat memenuhi kebutuhan pebelajar BIPA. Selain itu, bahan ajar yang dipilih sebaiknya juga sesuai dengan standar kompetensi lulusan BIPA (SKL BIPA).

\section{REFERENCES}

[1] I. Suyitno, G. Susanto, M. Kamal, and A. Fawzi, "Cognitive Learning Strategy of BIPA Students in Learning the Indonesian Language," IAFOR J. Lang. Learn., vol. 3, no. 2, pp. 175-190, 2018, doi: 10.22492/ijll.3.2.08.

[2] R. K. Ningrum, H. J. Waluyo, and R. Winarni, "BIPA (Bahasa Indonesia Penutur Asing) sebagai upaya internasionalisasi universitas di indonesia," 1st Educ. Lang. Int. Conf. Proc., pp. 726-732, 2017.

[3] M. Yahya, A. Andayani, and K. Saddhono, "Hubungan Penguasaan Kosakata dengan Kesalahan Diksi Dalam Kalimat Bahasa Indonesia Mahasiswa BIPA Level Akademik," KREDO J. Ilm. Bhs. dan Sastra, vol. 2, no. 1, 2018, doi: https://doi.org/10.24176/kredo.v1i2.2121.

[4] W. Wiratsih, "Analisis Kesulitan Pelafalan Konsonan Bahasa Indonesia (Studi Kasus terhadap Pemelajar BIPA Asal Tiongkok di Universitas Atma Jaya Yogyakarta)," KREDO J. Ilm. Bhs. dan Sastra, vol. 2, no. 2, pp. 242-255, 2019, doi: 10.24176/kredo.v2i2.3061.

[5] Y. Yolanda, "Memperkenalkan Budaya Indonesia Melalui Pemanfaatan Pantun Sebagai Materi Pengajaran BIPA," Kongr. Bhs. Indones., 2018.

[6] I. Indrianti, "Developing student-centered grammar materials for beginners' level Indonesian," Electron. J. Foreign Lang. Teach., vol. 9, no. SUPPL.1, pp. 380-401, 2012.

[7] E. E. Prasetiyo, "Pengembangan Bahan Ajar Bipa Bermuatan Budaya Jawa Bagi Penutur Asing Tingkat Pemula," Ling. J. Bhs. dan sastra, vol. 2, no. 2, 2015.

[8] L. Nurlina, A. Andayani, R. Winarni, and S. Y. Slamet, "Kebutuhan Pengembangan Bahan Ajar Menyimak Bermuatan Budaya Lokal Jawa Tengah untuk Pembelajaran BIPA," 1st Int. Conf. Lang. Lit. Teach., pp. 734-738, 2017.

[9] S. Sumarti, I. Suniarti, and E. S. Agustina, "Lintas BUdaya (Interkultural) Dalam Pembelajaran Berbicara Bagi Peserta BIPA Darmasiswa Di Universitas Lampung," Konf. Int. Pengajaran Bhs. Indones. bagi Penutur Asing XI, pp. 357-370, 2019.

[10] F. Pangesti and A. B. Wiranto, "Pengembangan Bahan Ajar Bipa Berbasis Lintas Budaya Melalui Pendekatan Kontekstual komunikatif," J. Pendidik. Bhs., vol. 7, no. 2, p. 342, 2018, doi: 10.31571/bahasa.v7i2.1015.

[11] M. Arsanti, "Pengembangan Bahan Ajar Mata Kuliah Penulisan Kreatif Bermuatan Nilai-Nilai Pendidikan Karakter Religius Bagi Mahasiswa Prodi PBSI, FKIP, Unissula," KREDO J. Ilm. Bhs. dan Sastra, vol. 1, no. 2, pp. 71-90, 2018, doi: 10.24176/kredo.v1i2.2107.

[12] M. D. Gall, J. P. Gall, and W. R. Borg, "Educational Research: An Introduction, 8th Edition," Educ. An Introd., 2006.

[13] Y. A. Sriwulandari and A. A. Ramadhani, "Pengembangan Bahan Ajar BIPA Darmasiswa IKIP Budi Utomo Malang," J. Ilm. Ilmu Pendidik., vol. 1, no. 3, pp. 90-93, 2018.

[14] A. A. Ramadhani, "Analisis Kebutuhan Belajar Untuk Menyusun Perangkat Pembelajaran Bipa Tingkat Pemula Yang Berorientasi American Council for Teaching Foreign Language (ACTFL)," Paradig. J. Filsafat, Sains, Teknol. dan Sos. Budaya, vol. 23, no. 2, pp. 19-28, 2017, doi: 10.33503/paradigma.v23i2.326. 
[15] D. Hartono, "Wisata Kuliner Nusantara: Diplomasi Budaya Melalui Standarisasi Materi Ajar BIPA Di Era Milineal," Konf. Int. Pengajaran Bhs. Indones. bagi Penutur Asing XI, pp. 162-176, 2019.

[16] A. Kusmiatun, "Topik Pilihan Mahasiswa Tiongkok Dalam Pembelajaran BIPA Program Transfer Kredit Di UNY,” J. Penelit. Bhs. Sastra dan Pengajarannya, vol. 15, no. 1, 2016.

[17] F. Junaidi, R. Andhira, and E. Mustopa, "Implementasi pembelajaran BIPA berbasis budaya sebagai strategi menghadapi MEA," 1st Educ. Lang. Int. Conf. Proc. Cent. Int. Lang. Dev. Unissula, pp. 317-324, 2017.

[18] R. Rahim and S. Syamsuri, "Pembelajaran Bahasa Indonesia Berbasis Kearifan Lokal Bagi Darmasiswa Di UNISMUH Makasar," Simp. Int. Pengajaran BIPA, pp. 1-910, 2017, [Online]. Available: https://bipa.kemdikbud.go.id/filebakti/403Kumpulan_Esai_SIPBIPA_2017.pdf.

[19] N. N. I. Sariningsih, I. N. A. J. Putra, and N. K. Wedhanti, "An Anlysisi of Culture Shock of BIPA Students In UPT Bahasa," J. Pendidik. Bhs. Ingg. UNDIKSHA, vol. 5 , no. 2, 2017, doi: 10.23887/jpbi.v5i2.13325. 